Article

\title{
Understanding Land Use and Rural Development in the National Scheme of Village Relocation and Urbanization in China: A Case Study of Two Villages in Jiangsu Province
}

\author{
Qidong Huang ${ }^{1, *}$, Jiajun $\mathrm{Xu}^{1}{ }^{1}$, Hua Qin ${ }^{2}{ }^{-}$and Xinyu Gao ${ }^{3}$ \\ 1 School of Public Administration, Hohai University, Nanjing 211100, China; xujiajun2004@126.com \\ 2 Division of Applied Social Sciences, University of Missouri-Columbia, Columbia, MO 65211, USA; \\ qinh@missouri.edu \\ 3 School of Finance and Public Management, Anhui University of Finance and Economics, \\ Bengbu 233030, China; gxy2013kbcg@163.com \\ * Correspondence: huangqidong@hotmail.com; Tel.: +86-258-378-7376
}

Received: 30 July 2018; Accepted: 6 September 2018; Published: 10 September 2018

\begin{abstract}
Large-scale village relocation and urbanization, one of the most significant social changes in China, bring villages both development opportunities and social risks. The social risks mainly stem from the government's strong position in land expropriation and policy preference for urban development. We observe the amalgamation of Anyang and Bomu Village in China and explore the specific role of land policies in the social change and restructuring of the two villages. We find that clan gentries challenge the government's "absolute" authority over land and landless villagers start the trend of "de-urbanization." Our research presents targeted policy recommendations in terms of weakening the role of the government in urbanization, strengthening dialogues between the government and clans and coordinating urban and rural land use.
\end{abstract}

Keywords: land use policy; village relocation; urbanization; rural development

\section{Introduction}

China, the most populous developing country in the world, has been implementing a National Scheme of Village Relocation and Urbanization since the beginning of the 1980s which imposed a large-scale and continuous rural land expropriation and exercised unified rural planning to achieve rapid urbanization. The scheme has gone through three stages. In its first stage (1980-1990), the scheme encouraged rural-to-urban migration to solve the problem of employment of surplus rural labor and raise farmers' income. At this stage, only labor mobility was involved and the size or the number of cities of various scales remain unchanged. In the second stage (1991-2000), the scheme encourages the rapid development of township enterprises (especially those in coastal areas), which attracted skilled migrant farmers to return to towns and villages from cities. This has caused the expansion of the area of towns and decline in the number of villages. In the third stage (2001-present), the scheme supports the expansion and development of towns, cities, metropolis and megalopolis and a large number of villages are merged [1,2].

Some data might reflect some basic features of China's urbanization. In 1980, there were 193 cities in China and the proportion of urban land area to the total land area of the whole country was $6.8 \%$. While in 2017, there were 698 cities and the proportion increased to $21.8 \%$, with an average annual increase of $12.6 \%$. From 1999 to 2017, the numbers of villages reduced from 801 thousand to 570 thousand in China, a decline by approximately 30\% [3,4]. In recent 10 years, local governments 
in China have taken the form of village merger or village adjustment to promote the process of urbanization, during which the boundary of villages is broken and resources are reconfigured. The conflicts inside a village reduced while that between villages intensified and this has significant and profound impacts on the structure of rural society $[5,6]$.

An increasing number of studies has been conducted on the social aspects, focusing social problems like household recovery, population flow and inclusive development [7-9]. Considering the orientation of this research, we divide the relevant research into three parts. The first focuses on clans and rural land expropriation. A clan usually derives from the same ancestor and lived in the same village. The deep foundation of a clan is that, as a kind of social organization, it is formed in such a pre-endowed social relationship as consanguinity $[7,8]$. The relative closed living space and common moral norms strengthened the consciousness and concept of the clan. A village may consist of one or more clans of different sizes. Villagers in the same village may belong to different clans. Due to the impact of various social relations (like land relations) and the influence of heterogeneous cultures (which might be caused by population flows), the internal norms and mutual relations of clans show strong flexibility. Research has reported that clan was a kind of institutional structure of villagers to accommodate changes initiated by land expropriation or land use change $[9,10]$. Research also found that clan, a social organization of united villagers, might check and balance rural power in land expropriation more effectively than villagers as individuals. Clan power reduces the damage to the villagers caused by the alienation of land power to a certain extent $[8,11,12]$.

The second theme is concerned with land planning policy. Local governments often follow the principle of "State Interest First" and pursue the maximization of land development, which means local or community interests are often neglected and prioritize the development of urban areas over that of rural villages. Some research holds the viewpoint of "symbiosis," emphasizing that the social systems of urban and rural areas complement each other and co-develop based on reciprocity [6,13,14], while other research emphasizes the importance of the non-equilibrium of urban and rural development and suggests that rural development might be driven by land expropriation and moderate advanced urban economy $[15,16]$. Some local governments prefer large-scale leases to small-scale ones for land that must be used for agricultural production [17].

The third cluster is mainly related to de-urbanization, which refers to the trend of some urbanized villagers returning for various reasons to the countryside. Some studies concluded that they leave cities because they cannot enjoy the same public services as urban residents or fail to adapt to city life $[17,18]$, or because they have to go back to take care of the elderly or left-behind children [15,19]. Some other research find that some villagers are back to the countryside as they choose to return to villages to engage in new types of agriculture (such as sightseeing orchards or farms) or new rural construction (a strategy proposed by the Chinese government in 2005 to stimulate rural development) [20-22]. In view of this trend, the state proposed a new macro strategy of harmonious development of urbanization and de-urbanization in the National People's Congress in 2018, which emphasizes the complement of urbanization process and rural development.

Some of the existing studies on de-urbanization emphasize that both urbanization and de-urbanization urgently require more specific and diversified policies that are compatible with the local environment [23,24], while others warn people of a dangerous idea behind the growing trend of de-urbanization, that is, significant differences in social development between urban and rural areas are mainly attributed to the large demand for resources by cities. These studies emphasize that the development of cities actually provides important resources and advanced frameworks for promoting the development of rural areas $[25,26]$. We must point out that the unique relationship between the state power and rural society behind the impact of land policy is always neglected when land policies are discussed. The uniqueness is manifested by the interpenetration of the state order (in the form of policies and laws) and the norms of rural society (in the form of habits and authority). Villages are neither independent from state domination nor entirely subordinate to state politics. There has been no real autonomy in rural areas because the concept of popular sovereignty or social contracts has 
not been extensively and deeply developed in rural affairs [4]. China's rural society is a kind of "spontaneous order" based on the authority of clan gentries and conventions of villages [5].

Now the state tries to completely replace this spontaneous order by penetrating its power into the countryside in different ways such as land expropriation and village merger [10]. Thus, the rural society is being affected by the new rules of resource allocation and the formation of new interest groups. However, even if the state needs to enhance its control over the countryside by resource allocation and social mobilization, the basic habits, customs and norms, which have never completely disappeared, are the basic conditions for China's rural development [22].

To gain a better understanding of land policies' effects on social development of traditional villages and provide policy implications related to traditional villages in China, we closely observe the specific role of land policy in the social restructuring of traditional villages, with emphasis on negotiations between clans and local governments, the rise of de-urbanization and the impacts of land use on village merger. Based on our observation and discussion, we present targeted policy recommendations in terms of reducing the role of the government in urbanization, strengthening dialogues between the government and clans and coordinating urban and rural land use.

Admittedly, there are a lot of factors such as the flows of seasonal labor and the outmigration of young people affecting traditional villages but these factors are more or less related to land use in rural villages [23]. Moreover, although rural transformation has been underway slowly before the implementation of land expropriation in traditional villages, some major land policies have no doubt led and speeded up social, economic and environmental changes and thus become an important contributory factor in rural transition [24,25].

The remainder of the article is organized as follows. Section 2 describes our research methods and data and Section 3 presents findings related to the ancestral hall reconstruction, land expropriation and land development and lease. After providing interpretations of the results in Section 4, we conclude with implications for future rural land and development policies in the final section.

\section{Methods}

\subsection{Study Area}

Anyang and Bomu were once two adjacent villages located in the southern suburb of Liyun City, Jiangsu Province (Figure 1). Anyang was a traditional village with 880 people (175 households), in which clan convention played an important role in maintaining the village order. Anyang villagers made their living by planting Chinese herbs and making bamboo wares or handicrafts. Bomu was a relatively diversified and modernized village with 1489 people (295 households) and the influence of the clan tradition, although still existing, was gradually disappearing. Most of the Bomu villagers were engaged in business (e.g., transportation, retailing or catering).

Anyang was relocated and merged into Bomu due to the south expansion plan of Liyun during 2013-2016 (Anyang no longer existed after May 2015). Majority of the Anyang villagers refused to relocate at the beginning but they finally agreed not only because the government have provided new housing to them and promised to help them find jobs but also because clan gentries' strong objections to relocation gradually softened. Liyun Municipal Government respectively expropriated $75.3 \%$ and $65.2 \%$ of the land from Anyang and Bomu and built a medical industrial park on the expropriated land. The land which was not expropriated was allocated to clan members or villagers of both villages according to the actual labor force of each family. Provincial Bureau of Land Administration and Liyun Municipal Government were responsible for land use planning and the Hedian township government for implementation of the plan.

All agricultural land and villagers' homesteads of Anyang Village are expropriated. Of the land expropriated, $25 \%$ is still used for agricultural production, $65 \%$ for industrial park construction and $10 \%$ for infrastructure such as water conservancy and roads. The land used for agricultural production may be leased out but required to be leased in a large area as a whole (at least 180,000 $\mathrm{m}^{2}$ ) and not 
allowed to be leased separately. Agricultural production on the land leased is subject to environmental assessment organized by local government. Some homesteads of Bomu Villagers are expropriated for the construction of government-planned resettlement apartments. All landless villagers will be included in the pension system and will receive subsistence allowance of CNY1100 (approximately USD161) every month.

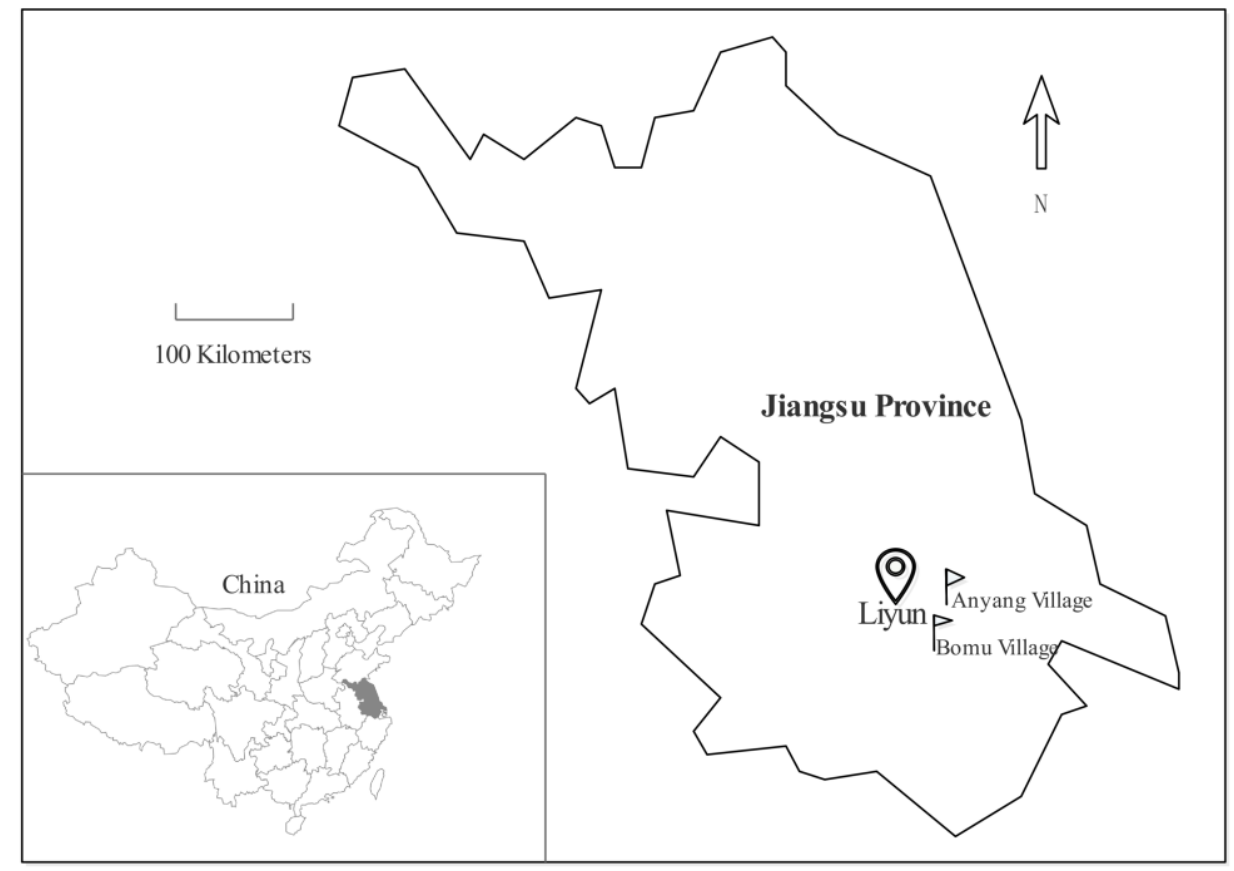

Figure 1. Map of Jiangsu Province and Location of Anyang and Bomu Village.

There are two ways of compensation for villagers' homestead. One is equivalent replacement. Villagers may choose their own apartments from government-planned resettlement apartments with any excess payment being refunded and any deficiency repaid. The other is direct financial compensation. The villagers are compensated for CNY150,000 to CNY200,000 (approximately USD21,997 to USD29,329) according to financial assessment. They can also get an additional compensation fee of minimum CNY20,000 (approximately USD2932) for transitional periods. The scope of compensation is not limited to housing and homestead but also to orchards, vegetable gardens and wells. The local government will arrange skill training and provide employment information for the villagers free of charge.

\subsection{Data Collection, Conceptualization and Analytical Framework}

We adopted semi-structured interviews, participatory observation, conversation analysis and informal interviews to conduct qualitative analysis. Our interviews or discussions revolved around the assumptions concerning land policies mentioned in the introductory section and analyzed the effects of land policies.

We conducted eight semi-structured interviews with officials of Liyun and the township government to understand their land use policy in January 2017. The subjects interviewed included the heads of the Municipal Bureau of Land Planning, the Municipal Bureau of Environmental Management, the Municipal Bureau of Public Security and the village heads of Anyang and Bomu. We focused on the following questions when we interviewed the officials: (1) how the government determine the scope and scale of land expropriation (2) whether the government considered the different tradition and appeals of the villages (3) whether the government plan the land use considering the diversity of the village background (4) whether the government made appropriate adjustments to land planning according to the actual situation. We comprehensively analyzed the recorded dialogues and collected 
data to understand the attitudes and measures of governments at different levels and objectively evaluate the effects of the land policies on different villages.

We had 35 semi-structured interviews with different types of villagers from July to September 2017. We classified the landless villagers into two types: the villagers who successfully adapted to urban life or started a business in cities and the villagers who failed to adapt to urban life and returned to the village. We randomly selected the villagers interviewed and discuss the following topics with them: (1) how loss of land affects them (2) why some villagers stayed in cities while the others left (3) how the villagers who returned to villages live and work in the villages (4) what were the different impacts of same land policies on villagers from different villages. We focused on the impact of different land policies on villagers' social status and livelihoods.

We held five informal interviews with the clan gentries and the elites (randomly selected from both villages) in February 2018. We asked the clan gentries and elites about their views on land expropriation and the measures they took. We also participated and observed all the three rounds of Joint Conference of Clan Gentries-Elites-Township Officials and interviewed them after the meetings about the purposes of the meetings and their views on the land policy and use. We analyzed discourse, negotiations and even quarrels at these events.

An analytical framework is introduced to guide the evaluation of the impact of land expropriation on rural development (Figure 2). We start from the specific background of rural areas, observe land expropriation, land development and leasing land, discuss the results from economic (livelihood recovery), political (power flow and pollical participation) and social aspects (social reconstitution).

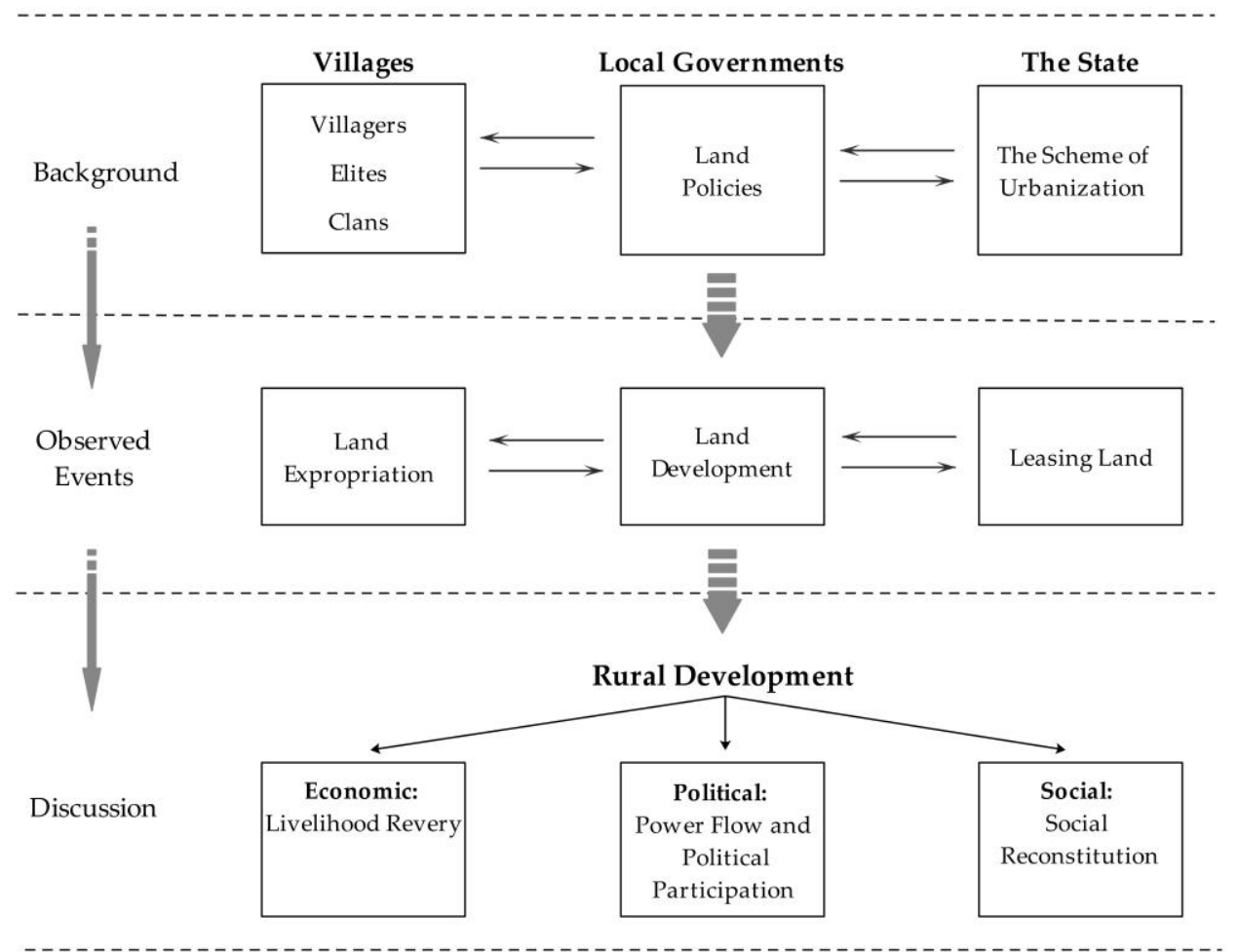

Figure 2. An Analytical Framework for the Evaluation of the Impact of Land Policy on Rural Development.

\section{Results}

\subsection{Land Expropriation and the Ancestral Hall Reconstruction}

There were fundamental differences between the views of the government and the clan members on land expropriation: The Liyun Municipal Government claimed that the state, as the ultimate owner of the land, had the final right to dispose of all the land, especially in the national schemes of urbanization, while the clan members of Anyang claimed that the land expropriation weakened not 
only their material base but also the clan's spiritual foundation. Some clan members explained that the clan had planted crops, herbs and bamboo on the land for more than 500 years and had formed a deep feeling for the land. More importantly, they firmly opposed demolishing an ancestral hall, which was built one hundred and twenty years ago and had been the main place for clan meetings and ritual activities. The clan gentries organized three protests and demonstrations against the Liyun Municipal Government during January 2014.

Under pressure from the clan, the municipal government authorized the township government to meet and negotiate with five representatives of Anyang in February 2014. The five representatives consist of two clan gentries, traditional clan seniors with noble characters and high prestige and three elites, the rising younger villagers in economic fields. After three rounds of talks, they agreed on the following two points. First, the clan gentries understand the necessity of the national schemes of village relocation and urbanization and would persuade the clan members to agree to comply with the government's plan. Second, the municipal and the township government respected the tradition of the clan and decided that a plot of 0.32 hectares, on which stand the ancestral hall, would not be appropriated. The government would redesign and rebuild the ancestral hall for safety reasons, with all the incurred cost borne by the government. The government also decided that 0.48 hectares of bamboo forests around the ancestral hall would not be expropriated and five prestigious bamboo ware artists of the clan were given responsibility for the care and use of the bamboo forest.

The reconstruction of the new ancestral hall was completed at the end of December 2015 and the new hall continued to be the most important patriarchal symbol that represents the clan culture and tradition: it was not only one of the key places for important clan meetings and sacrificial activities but also a local cultural center for exhibition of bamboo handcrafts. It plays an essential role in protecting endangered clan customs, improving traditional handicraft techniques and maintaining social stability.

The township government, after recognizing the importance of cooperation with the gentries and elites, formed Joint Conference of Clan Gentries-Elites-Township Officials with the two villages. In the subsequent planning and construction of the new village, the township made some adaptable adjustments to the village planning or design after holding the joint meetings. Based on the suggestions or resolutions made in the meetings, the township government built some facilities dedicated to improving the livelihood of the clan members such as a community library, a community clinic and a villagers' cultural center on small plots of land reserved within its authority. Besides, the township officials and the secretary of the Party branch of the villages not only asked building contractors to train and recruit villagers but also encourages elites to set up companies to provide catering and building materials services for the contractors. However, the township officials acknowledged that all their attempts were not supposed to obstruct the development and land expropriation plans made by the Liyun Municipal Government.

\subsection{Land Development}

The Bomu villagers collectively owned 390.1 hectares of land for cultivation after land expropriation. However, the land they owned was facing serious soil erosion and pollution. As the grassland and woods surrounding the land were destroyed, the land was suffering soil nutrition loss and imbalance. Loss of nutrient elements greatly reduced land productivity. Some areas of the land even show a sign of desertification under the conditions of drought and windy weather and some ponds nearby were almost silted up. In addition, the land was being polluted by waste from several pharmaceutical and medical consumable factories next to it. The villagers complained that few land gains from expropriated land were used to protect and develop the land for agricultural use as planned.

Moreover, a lot of land expropriated by the government was unused. It is estimated that $42.3 \%$ of the 1148.7 hectares of land levied from Anyang Village were idle since it was expropriated three years ago. This, according to some officials and villagers, was caused by two factors: First, the rigidity of unified land planning was difficult to meet the needs of the diversity of local land development. For example, the Liyun Municipal Government built a modern medical industrial park even if 
Anyang and the township recommended the development of traditional Chinese medicine related industries. The Liyun Municipal Government clearly rejected the proposal by claiming that the municipal government must obey and implement the unified land development plan formulated by the central and provincial government. Second, some commercial capital as well as the government usually adopted the strategy of "enclosure instead of use" (i.e., build walls around but reluctant to develop the land) in order to gain value-added revenue, which has led to the decline of the overall efficiency of urban land use. Some investors even managed to change the original plans of the land so as to achieve more profits.

Heads of the two villages and clan gentries complained that land pollution and disuse have brought great negative impact on their livelihoods and health. Under the pressure from the villages, the township government established the Office for Land Consultation, where the villagers, officials from the land or environmental protection divisions of the township and managers of the enterprises meet to discuss the issues concerning land use. However, the divisions could only play a very limited impact on the problems because regional and local administrative structures have led to their "conflicting status." Vertically, the divisions are under the technical supervision of the departments at higher levels, while horizontally they must accept the executive leadership of local governments, which actually controlled the budget planning of the divisions. The divisions might make inappropriate land or environmental policies under the pressure of local governments.

Moreover, as the actual law enforcement bodies, the land or environmental divisions at the township level faced many state-owned enterprises or foreign-funded enterprises associated with higher administrative levels. The budgets and personnel of these divisions might be affected when strong economic interest groups threaten local government by lobbying or investment diversion. The land or environmental divisions were in fact squeezed by the strong coalition of local governments and enterprises. Although the vertical management at the provincial level has been implemented, its effectiveness is still to be observed because of the gradualness of the reform.

\subsection{Leasing Land}

With the village relocation and land expropriation, about $48.2 \%$ of the Anyang villagers and $24.6 \%$ of the Bomu villagers became landless and their income was considerably reduced. The number of villagers who went to cities to find jobs would presumably increase because they were supposed to improve their livelihoods through diversified career development. However, the number of landless villagers who worked in the cities actually declined from 206 in October 2015 to 82 in October 2017 and $75.3 \%$ of the villagers who left the cities chose to return to their villages to find jobs.

This trend of return migration, according to some villagers, is mainly due to three factors: first, it is difficult for the villagers to find jobs in the nearby cities since many factories in the cities move to areas where labor costs were relatively low or had automated production due to rising labor costs. Second, many villagers claimed that they were basically farmers instead of workers or waiters and their final choices and destinations were still agriculture although they were currently engaged in non-agricultural work. Third, the villagers were deeply troubled by the problems of their children's education. It is difficult to enroll migrant children in public primary or junior schools with low tuition fees in the cities where their parents work due to the strict household registration policy. They have to go to poorly constructed school set up specifically for migrant children. Meanwhile, the children who are left behind have to stay with their grandparents, which causes a host of social problems such as lack of parents' companionship and juvenile delinquency.

Most of the villagers returning from cities still wanted to engage in agriculture-related work, such as flower planting, animal breeding or tourist farm operation. However, they complained that it was difficult for them to lease the right land in time because of tedious approval procedures or poor infrastructure. The government always gave priority to land leases with large investment while postponed the villagers' application which were usually of small investment. Since it was not politically right to openly reject the villagers' applications, officials usually used everyday obstructions, 
by setting a series of small obstacles, such as shortening the opening time of small land lease offices, lengthening the examination and approval time and using complex forms, to hinder their application progress. Even if they succeed in renting the land, the villagers often faced high rental fees, poor water conservancy or incomplete electric power facilities.

Those who failed to lease land from the government found that it was very hard to find jobs with most of the enterprises in the new village since the enterprises were run or managed by the Bomu elites who tended to hire Bomu instead of Anyang villagers. Some clan gentries noted the prejudice and held rounds of clan meetings of the two villages to discuss it. After several talks, they jointly formulated some rules of impartiality for dealing with relevant affairs. The original aim of the rules was to ensure equal pay for equal work and opportunities for job opportunities. In the following months, these rules were constantly improved and eventually formed a "Grassroots Constitution" which called for inclusive development of the two villages and stipulated the equality of the villagers. The villagers said that the constitution was "small (simple)" but "magical": it not only secured them job opportunities in the new village but also guaranteed them the right to present their own opinions in village meetings.

\section{Discussion}

\subsection{Acquiescent Notions That Guide the Current Land Policies}

What deserves our further investigation in this section are some default or acquiescent notions that guide the current land policies in urbanization. The first is concerning the ownership of land: The state, as the ultimate owner of the land, has the right to dispose of any land arbitrarily. In traditional Chinese society, the state's reach into the countryside and the maintenance of the rural order basically relies on the "gentry rules" and traditional moral system, following the principle of "the power of clans lying outside the direct authority of emperors." Land, as an asset of clans, is completely owned and dominated by clans [26,27]. However, the current system of land ownership in China follows the principle that all land rights are being granted by the state, which contains the political ideal of excluding the private ownership and the elimination of exploitation. The incompleteness of villagers' land property rights leaves the institutional possibilities for the government to infringe the land rights and interests of the villagers. Moreover, the strict hierarchical system of power also adds to the obstacles to the adaptation of land planning to complex situations [26]. For instance, the bureaucratic examination and approval system makes it difficult for the land planning to include the demands of the villagers or to execute some adaptable project variation.

The second is about the utilization of land: The development of urban economy should be given priority to that of rural economy and the development of rural areas is largely dependent on land expropriation and urbanization. China's urbanization, heavily depending on land expropriation, is accelerating in the past decades. The lower the economic and social development of a region is, the more the local government hopes to seek the rapid growth of fiscal revenue by speeding up the process of urbanization. Although it has increased the fiscal revenue in a short time, the rapid urbanization has permanently changed the clans' environment and the villagers' living ways. Under the policy of urban priority, the sustainable development of rural areas has been seriously challenged [25].

The third is concerning land use efficiency: the assumption that urban land use efficiency is higher than that of rural land use. On paper, compared with that of rural land, the use of urban land is indeed a more intensive form of land use under certain circumstances [23]. If rural population is properly relocated and rural land is scientifically planned and used, urbanization has the potential to maximize the efficiency of land use. In reality, the government always forcibly expropriates land in the name of "improving land efficiency" or "coordinated urban-rural development" to seek the maximization of fiscal revenue [26]. Moreover, pollution or irrational land use have reduced land efficiency and aggravated the rural social risk. 


\subsection{The Current Land Policies' Effects on Rural Development}

\subsubsection{Livelihood Recovery}

The villagers who lost their land in the process of rapid urbanization directly face the problem of livelihood and employment. Most of the landless villagers have to leave their villages and work in cities except that a small number of landless villagers can stay in the villages and work for the construction of the new village as brick-layers or steel-fixers with the assistance of the township government. However, the job opportunities in the village are still relatively few compared with the number of landless villagers. Many of them (especially the elderly) find that it is hard for them to adapt to the city life within short time due to the long-term isolation between cities and countryside. They regard themselves as landless villagers and seasonal migrant workers instead of city dwellers. They experience great difficulties in their process of individual urbanization.

Aborted urbanization brings de-urbanization: a considerable number of villagers, who work in cities but fail to fully adapt to the new life, begin to return to the countryside. The de-urbanization brings about significant return tides and the shortage of land supply in the new village. It is not easy for the villagers who have returned home to lease suitable land to develop agricultural industry. Undoubtedly, the interests of the villagers were damaged during the national scheme of urbanization which is initially designed to integrate and optimize rural resources and benefit the villagers involved.

At a deeper level, in addition to the loss of land, the villagers might also lose a series of relevant capacity for action, such as the abilities to compete for job vacancies and resist environmental risks. These abilities are hard to recover since they were forced to transform from a familiar, convenient and favorite way of life to a strange, difficult way. The loss of land has already had great passive impact on their personal knowledge, skills, social circles and decision-making abilities.

Land policies themselves must also be sustainable in mechanism by integrating the strategies of dynamic and sustainable livelihoods. The reconstruction of the new ancestral hall and the exhibition of bamboo handcrafts in the village demonstrate that the land policy taking account of "dependency paths of livelihood" such as the historical tradition and cultural background of the villages has combined the short-term quality of life with the long-term development goals of villagers. The sustainability of the land policy might prevent landless villagers from being trapped in social exclusion in the process of urbanization.

\subsubsection{Power Flow and Political Participation}

China establishes centralized political structures to ensure the effective implementation of policies and quickly mobilization of resources. Although China has carried out political reform in the 1990s, it is difficult for the rigid vertical power system to respond flexibly to challenges brought about by the changes of the horizontal social network (such as village relocation, population flow or clan transition), which means that the effectiveness within the power hierarchy cannot be effectively converted into that in social governance. The Liyun Municipal Government, located in the top-down political hierarchy, must obey and implement the unified development plan formulated by the central and provincial government while choosing to refuse the town government's and the clan's proposal of suspending the operation of pharmaceutical factories. Obviously, the Liyun Municipal Government has ensured the effective completion of the political tasks of village relocation and land expropriation but failed to ensure sustainable development of the related villages.

The government always posits urbanization as the expansion of administrative areas and the increase of the number of industrial zones. There are always problems at the local level: when the local government implements the scheme of urbanization, it attempts to promote the urbanization through large-scale village relocation and land expropriation but this always results in "urbanization of land" being faster than the "urbanization of villagers"; It successfully makes efficient use of some land but wastes the remaining land; It tries to promote community integration by relocating villagers but only to find that the relocated villagers are always regarded as "outsiders"; It intends to reinforce its 
governance through merging villages and streamlining rural administrative institutions, only to find that it has undermined the social connections between the villagers. The space of village autonomy has been squeezed to some extent in the process of expansion and subsidence of state power in rural society.

However, rural society in China is being brought into a large national whole and the historical process which surpass the daily life of the clan members. This transition provides an opportunity for the innovative practice of villager autonomy-the top-down power subsidence forces the clan members to explore new models of autonomy, such as Joint Conference of Clan Gentries-Elites-Township Officials and Land Consulting Office. Clan members, who has linked their specific daily actions to the abstract power of the state through discussions on land policies, should be encouraged to conduct rural renewal in a self-organized way that is suitable for local conditions [28]. Meanwhile, gentries, although hardly granted with the power delegated from the above, might act as shock absorbers of the political system as well as protective layers for the clan members.

Benefiting from the practices of innovative autonomy, some wise cadres are increasingly making use of new mechanisms to reduce social and political conflicts. In the recent decades, some townships and counties have encouraged the rural consultation mechanism and system in rural China. The governments at different levels have come to realize that they are not only responsible to recover clan members' livelihood but also to cultivate their political capability of participation and ensure their effective and close supervision of the local governments.

\subsubsection{Social Reconstitution}

The clans usually regard their land as an important property "inherited from their ancestors" instead of "granted by the state," which means that any encroachment, occupation or destruction of the land by outside forces might cause strong resistance of the clans. Clan gentries or elders also ensure that the land is inherited by the principle of average inheritance: equal sharing out of land property among sons of families of extended families. Some ancillary structures on the land, such as historic ancestral buildings, are of great symbolic importance to clans. These structures, whose values are very hard to be measured in terms of money, are important places for clans to hold clan activities like clan meetings and sacrifices.

The rural non-institutional norms, the rules of social interaction, which spontaneously formed in the process of long-term social interaction of clans, have received tremendous impact from outside the countryside. The conservatism or stability of rural non-institutional norms is weakened by land expropriation, villagers' relocation, village reorganization and power sinking. However, the traditional rules of rural society have not been completely eliminated and are experiencing a slow transformation. There is a certain degree of integration between the informal norms and the formal system: the clan elders participate in the formulation of land policies as representatives of villagers.

Therefore, a new situation has been encountered in the rural society of China at present which greatly transcends the government's planning and the scholars' imagination: The formulation and implementation of the land policies have promoted the infiltration of state power into the rural society and this infiltration has led to the practice of semi-formal system, which is a combination of formal and informal system and the boundaries between them are dynamic. For example, role identification and behavior patterns of village cadres, clan elders or clan members have showed subtle changes since land expropriation: The secretaries of the Party branch of villages begin to play the role of national agents while the village heads represent the villagers' interests. Clan members are not only concerned about their own land interests but also began to elect their representatives to participate in the consultation and take part in the development plan of the whole village.

The new consultative mechanism like Joint Conference of Clan Gentries-Elites-Township Officials embodies the spirit and mode of social participation which cannot be found in the long-standing clan meetings. However, it is noteworthy that the democratic spirit embodied in the mechanism is seriously challenged by the inequality of social status: the appeals of the entrepreneurs who possess land are the more likely to be mentioned while that of the lower income or landless clan members are hard 
to be fully discussed at the meetings. If such consultation is constantly improved, the democratic dialogue based on the land issue will have spillover effect on the other issue of the villages. Once the consultation mode becomes the "new normal" of the villages, it will gradually eliminate the existing social inequality and promote the inclusive development of the villages.

\section{Conclusions}

Based on the observation and discussion, we conclude that urbanization is not only the transformation of rural production mode but also that of rural production relations. Such transformation has complicated effects on population mobility, livelihood restoration and public participation. In the process of urbanization, local governments are suggested to realize the inclusive and sustainable development of rural areas by regulating the conflicts of interests among different interest groups, establishing consultation mechanisms between clans and local governments and standardizing the operation of governments. Meanwhile, various rural forces, including clan or elites, are suggested to achieve effective villagers' autonomy through the transformation of land relations. Our case study also shows that social engineering carried out by the state to try to improve the human condition is likely to fail in terms of sustainability if it aims to achieve simplified state management, economic growth and rigid social stability.

Some policy implications are also drawn based our studies: First, reducing the role of the government in urbanization. The most obvious feature of China's urbanization is that administrative orders play a decisive and leading role in the whole process (especially in land expropriation and planning). We suggest that the government transition from the role of administrative executives to that of public service providers, public interest defenders and land market supervisors. The government is advised to expropriate land for public interest, not for financial revenue or political achievements. The government is suggested to reduce its dependence on the land finance and protect villagers' legitimate rights on land.

Second, strengthen the government's dialogues and consultation with clans. Clans and their members, possessing lasting value identification and closeness, usually have a natural dependence on consanguinity and geography. Village relocation, land acquisition and migration not only change their living spaces, production modes and social boundary but also break their sense of identity towards the groups and weaken their autonomy capability. The government is suggested to realize the importance of land to the development of clans and understand the key roles of land and land appendages to the inheritance of clan traditions. The government should establish consultation mechanisms between the government and clan gentries or elites and take into account the different characteristics of clans in land policy making. The government might manage to reconstruct the social connections within or across clans through rational arrangement and use of land, which are significant in maintaining villages' sustainable development [27].

Third, coordinate the urban and rural land use. The rural and urban systems are complementary to each other. China's rural sustainable development might face major challenges if the rural areas are sacrificed to ensure the priority of urban development and land is deprived of villagers in the name of urbanization. It is suggested that the local government better protect the interests of villagers by making the expropriation procedures transparent and ensuring the participation of villagers in policy making. After determining the subjects of land ownership, the government should ensure reasonable liquidity of land ownership and improvement of land resource efficiency by allowing the practice of renting, mortgaging, exchanging or shareholding [29]. The rational allocation of land resources is sure to promote the inclusive growth of urban and rural areas.

Author Contributions: J.X. and Q.H. contributed to the analytical model and investigation of the study. H.Q. contributed to design, preparation, theorization and improvement of manuscript. X.G. performed the data analyses.

Funding: This study was supported by a grant from Philosophy and Social Sciences Research Foundation of Department of Education of Jiangsu Province (Grant No. 2018SJA0026). 
Acknowledgments: We are thankful for the valuable suggestions from Sarah Rogers at University of Melbourne as we prepared the article. We also appreciate the comments from two anonymous reviewers and from the editors which are essential in the improvement of the article.

Conflicts of Interest: The authors declare no conflict of interest.

\section{References}

1. Yu, T.; Liu, N. Analysis of China's urban globalization and localization degree. Geogr. Geogr. Inf. Sci. 2005, 3, 23-27.

2. Cao, C.; Dong, L. Characteristics of development and evolution of small towns in China, Problems and Types of Planning and Regulation System. Agric. Econ. Probl. 2005, 3, 31-35.

3. Lichtenberg, E.; Ding, C. Assessing farmland protection policy in China. Land Use Policy 2008, $25,59-68$. [CrossRef]

4. Len, H.H. Urbanization in China: From imbalanced to balanced development. J. Nanjing Univ. 2016, 4, 34-43. (In Chinese)

5. Zhao, L. Governance of new type villages: Case study of resettled villages in China. China's Rural Observ. 2017, 5, 46-60. (In Chinese)

6. Wang, C.G.; Zhao, Y.F.; Wang, Y.Q. New trends of social stratification of contemporary Chinese peasants. Sociol. Res. 2018, 1, 55-65. (In Chinese)

7. James, L.W. Anthropological Overview: The Development of Chinese Descent Groups; Kinship Organization in Late Imperial China, 1000-1940; University of California Press: Berkeley, CA, USA, 1986; pp. $274-292$.

8. Wang, C.G.; Zhao, Y.F.; Wang, Y.Q. New trends of the social stratification of villagers in contemporary China. Sociol. Stud. 2018, 1, 21-32. (In Chinese)

9. Fried, M. Clans and Lineage: How to Tell Them Apart and Why, with Special Reference to Chinese Society; Bulletin of the Institute of Ethnography; Academia Sicica: Taipei, China, 1970.

10. Li, W.; Feng, T.; Hao, J. The evolving concepts of land administration in China: Cultivated land protection perspective. Land Use Policy 2009, 26, 262-272. [CrossRef]

11. Gao, J.; Wei, Y.D.; Chen, W.; Chen, J. Economic transition and urban land expansion in provincial China. Habitat Int. 2014, 44, 461-473. [CrossRef]

12. Shen, L.; Shuai, C.; Jiao, L.; Tan, Y.; Song, X. Dynamic sustainability performance during urbanization process between BRICS countries. Habitat Int. 2017, 60, 19-33. [CrossRef]

13. Qian, Z. Resettlement and adaptation in China's small-town urbanization: Evidence from the villagers' perspective. Habitat Int. 2017, 67, 33-43. [CrossRef]

14. He, X. On the regional differences in rural areas in China-A perspective of village social structure. Open Age 2012, 10, 108-129. (In Chinese)

15. Qiu, T. How Does the clan influence the implementation of land rights in villages? empirical study based on democratic election in villages. J. Nanjing Agric. Univ. 2018, 18, 72-86. (In Chinese)

16. Zhu, J.M. Transition of villages during urbanization as collective communities: A case study of Kunshan, China. Cities 2018, 72, 320-328. [CrossRef]

17. Liu, Y.; Fang, F.; Li, Y. Key issues of land use in China and implications for policy making. Land Use Policy 2014, 40, 6-12. [CrossRef]

18. Qin, H.; Liao, T.F. Labor out-migration and agricultural change in rural China: A systematic review and meta-analysis. J. Rural Stud. 2016, 47, 533-541. [CrossRef]

19. Li, L.H. Balancing rural and urban development: Applying coordinated urban-rural development (CURD) strategy to achieve sustainable urbanization in China. Sustainability 2017, 9, 1948. [CrossRef]

20. Gao, X.; Xu, A.; Liu, L.; Deng, O.; Zeng, M.; Ling, J.; Wei, Y. Understanding rural Housing Abandonment in China's Rapid Urbanization. Habitat Int. 2017, 67, 13-21. [CrossRef]

21. Tan, M.; Li, X.; Lu, C.; Luo, W.; Kong, X.; Ma, S. Urban population densities and their policy implications in China. Habitat Int. 2008, 32, 471-484. [CrossRef]

22. Khantachavana, S.V.; Turvey, C.G.; Kong, R.; Xia, X. On the transaction values of land use rights in rural China. J. Comp. Econ. 2013, 41, 863-878. [CrossRef]

23. Ming, C. Land politics embedded in the rural governance structure-Taking the rural society of modern China as the object of expression. Xuehai 2018, 2, 99-105. 
24. Qian, Z.; Xue, J. Small town urbanization in western China: Villager resettlement and integration in Xi'an. Land Use Policy 2017, 68, 152-159. [CrossRef]

25. Wang, P.; Wolf, S.A.; Lassoie, J.P.; Dong, S. Compensation policy for displacement caused by dam construction in China: An Institutional Analysis. Geoforum 2013, 48, 1-9. [CrossRef]

26. Wang, Z.F. Evolving landscape-urbanization relationships in contemporary China. Landsc. Urban Plan. 2018, 171, 30-41. [CrossRef]

27. Imai, K.S.; Gaiha, R.; Garbero, A. Poverty reduction during the rural-urban transformation: Rural development is still more important than urbanization. J. Policy Model. 2017, 39, 963-982. [CrossRef]

28. Wang, R.; Tan, R. Rural Renewal of China in the context of rural-urban integration: Governance fit and performance differences. Sustainability 2018, 10, 393. [CrossRef]

29. Yang, W.; Jiang, X.L. Evaluating sustainable urbanization of resource-based cities based on the mckinsey matrix: Case study in China. J. Urban Plan. Dev. 2018, 144, 55-70. [CrossRef]

(C) 2018 by the authors. Licensee MDPI, Basel, Switzerland. This article is an open access article distributed under the terms and conditions of the Creative Commons Attribution (CC BY) license (http:/ / creativecommons.org/licenses/by/4.0/). 